S. I.Zeghina,

M. Bounouala, Dr. Sc. (Tech.), Prof.,

M. Chettibi, Dr. Sc. (Tech.), Prof.,

A. Benselhoub, PhD
Laboratory of Valorization of Mining Resources and Environment, Badji Mokhtar University, Annaba, Algeria, e-mail: sara_imane@ymail.com

\title{
DEVELOPMENT OF NEW COMPOSITE CEMENT BASED ON WASTE ROCKS FROM DJEBEL ONK PHOSPHATE DEPOSIT (TEBESSA-ALGERIA)
}

Purpose. The main purpose of our research work involves the characterization and environmental management of waste rocks from Djebel Onk phosphate deposit. We propose a valorization of this product as an addition to cement manufacturing technique (the development of a new composite cement based on waste rocks of Djebel Onk phosphate deposit).

Methodology. A comparative study was conducted on the physical and mechanical parameters of the composite cement based on phosphate waste rocks with cement without additions (CWA) and other cements based on pozzolan and the blast-furnace slag additives. These additives make, respectively, at mass contents of 5, 10, 15, 20, 25 and $30 \%$ for each addition.

Findings. The studies and tests conducted have enabled us to deduce that it is clear that the use of phosphate waste rocks as an additive in the manufacture of cement gives better compressive strengths compared to other additives. Thus, this study has shown that it is possible to incorporate a considerable amount of phosphate waste rock from Djebel Onk deposit in the cement.

Originality. It becomes possible to reduce the amount of phosphate waste rocks of Djebel Onk for cost-effectiveness and eliminate their impact from the environmental point of view.

Practical value. The reuse of waste as an alternative raw material in building materials is a promising environmental solution. This way of valorization reduces large quantities of tailings and thus their environmental impact, as well as contributes to the preservation of non-renewable natural resources intensively used in construction (clays, limestone, sand, and others).

Keywords: phosphate waste rocks, blast-furnace slag, pozzolan, cement, additives, Djebel Onk deposit

Introduction. The mining waste produced continuously by the industrial activities is considered as major problems having a potentially negative impact on the environment and the economy of Algeria. The reuse of waste as an alternative raw material in building materials is a promising environmental solution. This way of valorization reduces a large quantity of tailings and thus their environmental impact, as well as contributes to the preservation of non-renewable natural resources intensively used in construction (clays, limestone, sand, and others) [1, 2].

Algeria has a significant deficit in building materials, especially cement. Facing the seriousness of environmental problems due to overexploitation of resources, the Algerian government decided in 2001 to devote an important financial envelope to achieve the objectives set out in the National Action Plan for Environment and Sustainable Development [3].

In the context of sustainable development and, especially, respect for the environment, cement producers were interested in the incorporation into cement of certain industrial by-products, likely to develop hydraulic properties [1, 4].

The need to find different types of cheaper cement with required physic-mechanical properties leads manufacturers to produce cements containing secondary clinker additives (natural or industrial by-products), with more or less significant proportions (mineral additives are widely used in order to largely solve the problem of national self-sufficiency in cements, as well as that of the reduction of the energy cost, thereby the clinker consumption decreases according to the rate of additions used).

The mineral additives often used in the manufacture of cement are mainly blast furnace slag and pozzolan $[5,6]$, other materials can be used as industrial waste (brick waste, marble waste, flax waste, phosphogypsum, fibber waste). These types of waste can be considered not only as waste but as by-products and a source of one or more elements of commercial value [1].

The approach of our study involves, first of all, characterizing the waste rocks of djebel Onk phosphate deposits, and then establishing a comparative study between the use of this type of waste as an addition in the production of cement and other additions such as blast-furnace slag (a by-product of

(c) Zeghina S. I., Bounouala M., Chettibi M., Benselhoub A., 2020 steel industry) and pozzolan (of natural origin) and even their influence on the quality of the studied cement CPJ-CEM II 42.5 (on physical parameters such as consistency, measurement of setting time and mechanical parameters such as simple compression).

Characterization of waste rocks from Djebel Onk phosphate deposit (Tebessa). Geographical location. The Algerian phosphate is exploited by the Phosphate Mining Company (SOMIPHOS) subsidiary of FERPHOS by the open pit method. This raw material is used largely for the manufacture of fertilizers and phosphoric acid. The Djebel Onk phosphate deposit is situated in Bir El-Ater about $100 \mathrm{~km}$ from Tebessa.

Characterization of phosphate waste rocks. The chemical and mineralogical composition of phosphate waste rocks is determined by using X-ray fluorescence and X-ray diffraction, respectively.

Chemical characteristics. The chemical analysis of the phosphate waste rocks of the different size fractions was carried out using a series of sieves nested on each other, whose opening dimensions are decreasing from top to bottom. Table 1 and Fig. 1 present the chemical analysis of particles size.

According to the chemical analysis data (Fig. 2) we note that the waste rocks contain all the elements found in limestone and clay $\left(\mathrm{CaO}, \mathrm{MgO}\right.$, and $\left.\mathrm{SiO}_{2}\right)$ However, limestone and clay do not contain $\mathrm{P}_{2} \mathrm{O}_{5}$. The phosphate waste rocks contain a very low $\mathrm{P}_{2} \mathrm{O}_{5}$ content so it is considered as a $\mathrm{P}_{2} \mathrm{O}_{5}$ poor material.

Mineralogical characterization. From Fig. 2 we see that the mineralogical composition of the original sample includes the following minerals: quartz, carbonate fluorapatite, albite, montmorillonite, orthoclase, dolomite, and calcite. However, it is noted that peaks of quartz, calcite and dolomite have a high intensity and are well expressed, which makes their identification easier.

Experimental part. In this work, we used the cement clinker of Ain Touta, the blast-furnace slag from El-Hadjar steel complex-Annaba(NE of Algeria), the pozzolan (a natural pozzolan of volcanic origin extracted from the Bouhamedi deposit located south of Beni-Saf-Ain Temouchent (NW of Algeria), and the phosphate waste rocks from Djebel Onk phosphate deposit. Gypsum as a fundamental additive in the cement is of local origin, we maintained a dosage of $4 \%$, for all the prepared cements for the following reasons: 
Chemical composition of the phosphate waste rocks

\begin{tabular}{|c|c|c|c|c|c|c|c|c|c|c|}
\hline contents & $\mathrm{P}_{2} \mathrm{O}_{5}$ & $\mathrm{CaO}$ & $\mathrm{MgO}$ & $\mathrm{SiO}_{2}$ & $\mathrm{Fe}_{2} \mathrm{O}_{3}$ & $\mathrm{~K}_{2} \mathrm{O}$ & $\mathrm{Na}_{2} \mathrm{O}$ & $\mathrm{SO}_{3}$ & $\mathrm{Cl}^{-}$ & LOI \\
\hline$(\%)$ & 1.69 & 28.04 & 14.39 & 25.28 & 0.88 & 0.25 & 0.31 & 0.18 & 0.017 & 28.70 \\
\hline
\end{tabular}

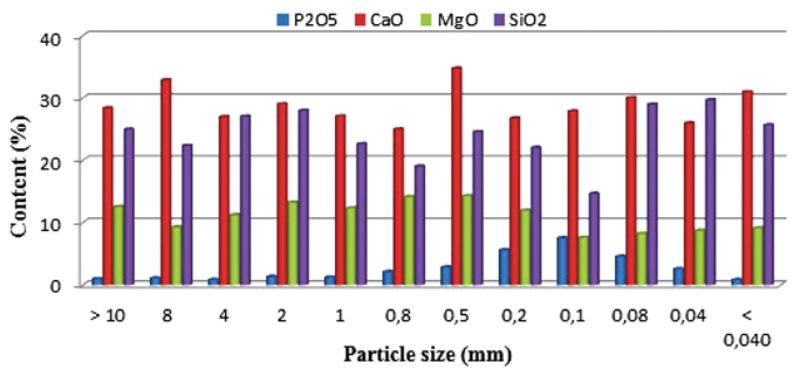

Fig.1. Evolution of the contents of the major constituents according to the different particle size of phosphate waste rocks

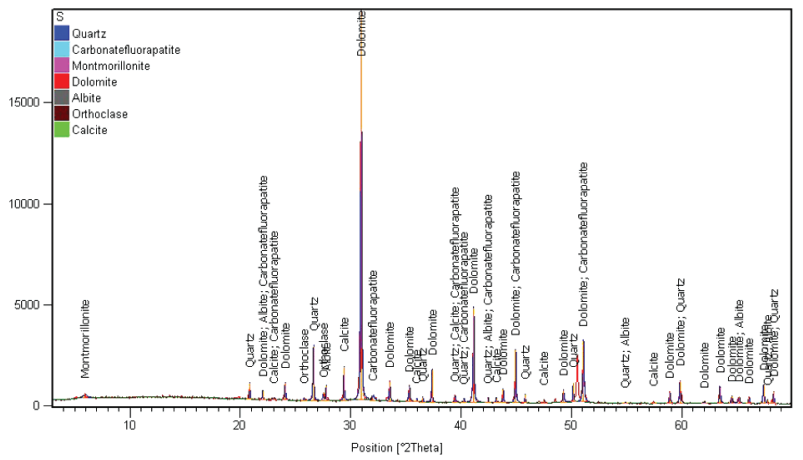

Fig. 2. X-ray diffraction spectrum of the initial sample of phosphate waste rock

- the quality of the gypsum is average;

- not to hide the influence of the additive content on the mechanical properties of the cement;

- to regulate the setting.

The chemical composition of the raw materials is given in Table 2.

Mineralogical composition of clinker. Based on certain hypotheses, Bogue (1929) developed a method that allows knowing the potential composition of main minerals $\left(\mathrm{C}_{3} \mathrm{~S}, \mathrm{C}_{2} \mathrm{~S}\right.$, $\mathrm{C}_{3} \mathrm{~A}$ and $\mathrm{C}_{4} \mathrm{AF}$ ) of a clinker, or cement from its chemical composition.

The numerical values of the mineralogical composition are given in Table 3.

$-\mathrm{C}_{3} \mathrm{~S}=4.07[\mathrm{CaO}(\mathrm{T})-\mathrm{CaO}(\mathrm{L})]-7.6\left(\mathrm{SiO}_{2}-\mathrm{RI}\right)-$ $-1.43 \mathrm{Fe}_{2} \mathrm{O}_{3}-6.72 \mathrm{Al}_{2} \mathrm{O}_{3}$

$-\mathrm{C}_{2} \mathrm{~S}=\left[2.865\left(\mathrm{SiO}_{2}-\mathrm{RI}\right)\right]-\left[0.754 \mathrm{C}_{3} \mathrm{~S}\right] . \quad \mathrm{RI}=0.21$

$-\mathrm{C}_{3} \mathrm{~A}=\left[2.650 \mathrm{Al}_{2} \mathrm{O}_{3}\right]-\left[1.692 \mathrm{Fe}_{2} \mathrm{O}_{3}\right]$

$-\mathrm{C}_{4} \mathrm{AF}=3.04 \mathrm{Fe}_{2} \mathrm{O}_{3}$.
Preparation of the mixtures: to study the influence of the additions on the quality of the cement we have prepared six mixtures for each type of addition (phosphate waste rocks, slag, pozzolan) and a control sample (CWA).

The starting mixtures are prepared according to the following proportions:

- Mixture 1: Portland cement without added (96\% clinker $+4 \%$ gypsum $+0 \%$ additive), is named CWA (CPA).

For phosphate waste rocks addition CPWR:

- Mixture 2:91\% clinker $+4 \%$ gypsum $+5 \%$ waste rocks), is named CPWR5;

- Mixture 3:86\% clinker $+4 \%$ gypsum $+10 \%$ waste rocks), is named CPWR10;

- Mixture 4:81\% clinker $+4 \%$ gypsum $+15 \%$ waste rocks), is named CPWR15;

- Mixture 5: $76 \%$ clinker $+4 \%$ gypsum $+20 \%$ waste rocks), is named CPWR20;

- Mixture 6: $71 \%$ clinker $+4 \%$ gypsum $+25 \%$ waste rocks), is named CPWR25;

- Mixture $7: 66 \%$ clinker $+4 \%$ gypsum $+30 \%$ waste rocks), is named CPWR30.

For the pozzolan addition $\mathrm{CP}$ :

- Mixture $08: 91 \%$ clinker $+4 \%$ gypsum $+5 \%$ pozzolan), is named CP5;

- Mixture $09: 86 \%$ clinker $+4 \%$ gypsum $+10 \%$ pozzolan), is named CP10;

- Mixture 10:81\% clinker $+4 \%$ gypsum $+15 \%$ pozzolan), is named CP15;

- Mixture $11: 76 \%$ clinker $+4 \%$ gypsum $+20 \%$ pozzolan), is named CP20;

- Mixture $12: 71 \%$ clinker $+4 \%$ gypsum $+25 \%$ pozzolan), is named CP25;

- Mixture $13: 66 \%$ clinker $+4 \%$ gypsum $+30 \%$ pozzolan), is named CP30.

For the blast-furnace slag addition CS:

- Mixture 14:91\% clinker + 4\% gypsum $+5 \%$ slag), is named CS5;

- Mixture $15: 86 \%$ clinker $+4 \%$ gypsum $+10 \%$ slag), is named CS10;

- Mixture $16: 81 \%$ clinker $+4 \%$ gypsum $+15 \%$ slag), is named CS15;

- Mixture $17: 76 \%$ clinker $+4 \%$ gypsum $+20 \%$ slag), is named CS20;

- Mixture $18: 71 \%$ clinker $+4 \%$ gypsum $+25 \%$ slag), is named CS25;

- Mixture 19: $66 \%$ clinker $+4 \%$ gypsum $+30 \%$ slag), is named CS30.

Physical characteristics of the cement paste. Consistency. The consistency to admit for having a good mortar is the quantity strictly necessary to obtain a plastic paste. The consistency

Chemical composition of materials by X-ray fluorescence

\begin{tabular}{|l|c|c|c|c|c|c|c|c|c|c|c|}
\hline & $\mathrm{SiO}_{2} \%$ & $\mathrm{CaO} \%$ & $\mathrm{MgO} \%$ & $\mathrm{Fe}_{2} \mathrm{O}_{3} \%$ & $\mathrm{Al}_{2} \mathrm{O}_{3} \%$ & $\mathrm{Cl} \%$ & $\mathrm{~K}_{2} \mathrm{O} \%$ & $\mathrm{Na}_{2} \mathrm{O} \%$ & $\mathrm{SO}_{3} \%$ & $\mathrm{P}_{2} \mathrm{O}_{5} \%$ & $\mathrm{LOI}_{\%}$ \\
\hline Clinker & 20.8 & 67.1 & 1.52 & 3.47 & 5.05 & 0.01 & 0.78 & 0.30 & 0.54 & & 0.27 \\
\hline Gypsum & 8.1 & 34.1 & 3.32 & 1.11 & 3.06 & 0 & 0.58 & 0.04 & 39.5 & & 10.0 \\
\hline Slag & 54.3 & 10.9 & & 2.69 & 12.3 & 0.02 & 3.42 & 0.0 & 0.56 & & 15.0 \\
\hline Pozzolan & 37.8 & 14.9 & 2.69 & 14.39 & 15.4 & 0 & 1.29 & 1.70 & 0.56 & & 17.8 \\
\hline Waste rocks & 25.2 & 28.04 & 14.39 & 3.41 & & 0.017 & 0.25 & 0.31 & 0.18 & 1.69 & 28.70 \\
\hline
\end{tabular}


Clinker mineralogical composition

\begin{tabular}{|c|c|c|c|}
\hline $\mathrm{C}_{4} \mathrm{AF} \%$ & $\mathrm{C}_{3} \mathrm{~S} \%$ & $\mathrm{C}_{2} \mathrm{~S} \%$ & $\mathrm{C}_{3} \mathrm{~A}$ \\
\hline 10.55 & 74.22 & 3.26 & 7.51 \\
\hline
\end{tabular}

\section{$\square C W A \backsim C P W R \square C P \square C S$}

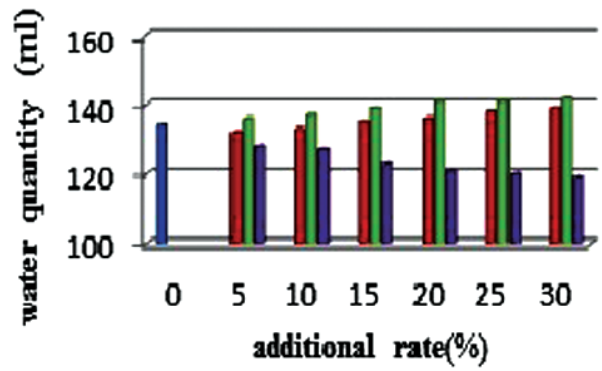

Fig. 3. Variation of the water quantity according to additional rate

of the cement is necessary to determine the start and end times of setting.

Corresponding to the reading of the histogram (Fig. 3), it is noted that the increase in the percentage of slag addition in the cement decreases the amount of water; on the other hand, the water quantity increases with the rise in the rate of the phosphate waste rock additive and pozzolan.

The variation of the decrease and the increase in the quantity of water is not the same when phosphate waste rocks, pozzolan and slag are added.

Table 4 indicates that the change in normal consistency is consistent with the Algerian standard requirements NA 229 [7] for all types of studied cements. For phosphate waste rocks and pozzolan additives the consistency is proportional to the addition rates; the more the addition rate increases, the more the consistency increases.

Setting time. The setting time corresponds to the passage of the paste or cement mortar from the fluid state to a more or less consistent state (mechanically resistant solid), measure- ments carried out using the Vicat apparatus. The results of tests are illustrated in Figs. 4, $a, b$ and $c$.

Based on Figs. 4, $a, b$ and $c$ we can say that: all the studied cements with additives have a setting time in accordance with Algerian standard requirements NA 442 [8], which imposes a minimum setting time of 60 minutes for the cement class CPJCEMII/A or B 42.5 .

Tests of mechanical compressive strengths: mechanical resistance studies on pressure are performed by the Blinder mechanical strength device.

The study is summarized to calculate the mechanical resistance to simple compression, varying the percentages of the additions from 5 to $30 \%$ with a step of $5 \%$, and respecting the Algerian standard requirements NA 234 [9] of composed Portland cements of the class (42.5).

In all tests, the Water/Cement ratio is maintained and equal to 0.5 . Concerning the storage conditions, the test pieces were stored in a storage room at controlled temperature and humidity $\left(T=20{ }^{\circ} \mathrm{C} \pm 1{ }^{\circ} \mathrm{C}, \mathrm{H}=95 \%\right)$ until the day of measurement (2, 7 and 28 days).

The mortars are composed of: $1350 \mathrm{~g}$ of normal dry sand (from the Leucate region (France) with an extra fine quartz, $225 \mathrm{ml}$ of water and 450 of cement they were prepared and poured into prismatic moulds of dimensions $(4 \times 4 \times 16 \mathrm{~cm})$ at the rate of six test pieces per test.

The results of the mechanical compression tests are reported in Table 5.

The analysis of the different types of additives Figs. 5, $a, b$ and $c$ and Figs. 6, $a, b$ and $c$, allows us to make the following comments.

The mechanical resistance to simple compression of the cement compound with different types of additives (CPJCEM II/A or B 42.5), are better compared to those of cement without additive (CWA-CEM I 42.5).

With fixation of age, it is noted that the more the percentage of addition increases ( 0 to $30 \%)$, the more the mechanical strength to the cement compression CPJ-CEM II/A or B decreases.

All types of studied cement having resistances in accordance to the requirement of the Algerian standard NA 442 [8].

The phosphate waste rocks additive confers the better mechanical resistance to simple compression for all ages and for

Variation in consistency as a function of the variation in the rate of addition for all types of studied cement

\begin{tabular}{|c|c|c|c|c|c|c|c|}
\hline \multirow{2}{*}{$\frac{\text { Type of cement }}{\text { Consistency }(\%)}$} & \multirow{2}{*}{$\frac{\text { CWA }}{26.8}$} & \multicolumn{2}{|c|}{ Cement with phosphate waste rocks addition } & \multicolumn{2}{|c|}{ Cement with added Pozzolan } & \multicolumn{2}{|c|}{ Cement with added Slag } \\
\hline & & CPWR5 & 26.4 & CP5 & 27.2 & CS5 & 25.8 \\
\hline & & CPWR 10 & 26.6 & $\mathrm{CP} 10$ & 27.4 & CS10 & 25.6 \\
\hline & & CPWR 15 & 27.0 & CP15 & 27.8 & CS15 & 25.4 \\
\hline & & CPWR 20 & 27.2 & $\mathrm{CP} 20$ & 28.2 & CS20 & 24.6 \\
\hline & & CPWR 25 & 27.6 & $\mathrm{CP} 25$ & 28.2 & CS25 & 24.2 \\
\hline & & CPWR 30 & 27.8 & CP30 & 28.4 & $\mathrm{CS} 30$ & 24.0 \\
\hline
\end{tabular}

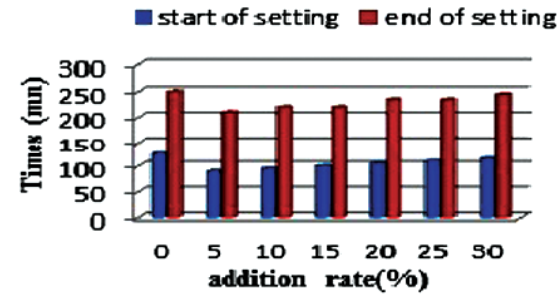

$a$

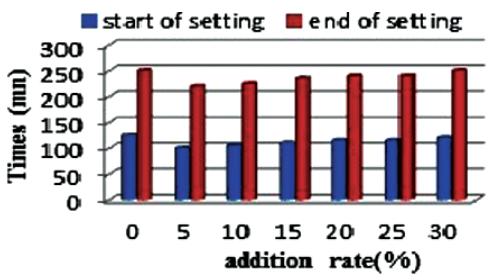

$b$

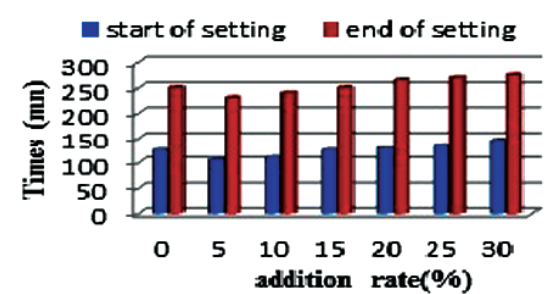

$c$

Fig. 4. Setting time as a function of different addition rate:

$a$ - setting time as a function of phosphate waste rocks addition rate; $b$ - setting times as a function of pozzolan addition rate; $c-s e t t i n g$ times as a function of slag rate addition 
Resistance to compression as a function of age for all types of studied cements

\begin{tabular}{|c|c|c|c|c|c|c|c|c|}
\hline \multirow{2}{*}{ Additive type } & \multirow{2}{*}{ Time } & \multicolumn{7}{|c|}{ Rate of addition } \\
\hline & & CWA & 5 & 10 & 15 & 20 & 25 & 30 \\
\hline \multirow{3}{*}{$\begin{array}{l}\text { Phosphate waste } \\
\text { rocks }\end{array}$} & 2 days & 25.35 & 31.40 & 30.25 & 29.60 & 29.05 & 27.08 & 22.85 \\
\hline & 7 days & 39.80 & 44.85 & 43.95 & 42.60 & 39.70 & 38.10 & 37.35 \\
\hline & 28 days & 50.25 & 54.45 & 53.35 & 52.75 & 50.75 & 49.65 & 48.40 \\
\hline \multirow{3}{*}{ Pozzolan } & 2 days & & 27.95 & 27.32 & 27.25 & 25.15 & 25.95 & 21.00 \\
\hline & 7 days & & 40.20 & 39.40 & 30.20 & 37.35 & 36.70 & 35.10 \\
\hline & 28 days & & 52.75 & 51.70 & 50.95 & 49.70 & 47.20 & 45.60 \\
\hline \multirow{3}{*}{ Slag } & 2 days & & 27.00 & 24.80 & 22.50 & 21.60 & 20.40 & 20.03 \\
\hline & 7 days & & 41.70 & 39.70 & 38.59 & 36.50 & 34.50 & 33.60 \\
\hline & 28 days & & 51.10 & 50.20 & 49.80 & 49.00 & 47.95 & 46.50 \\
\hline
\end{tabular}

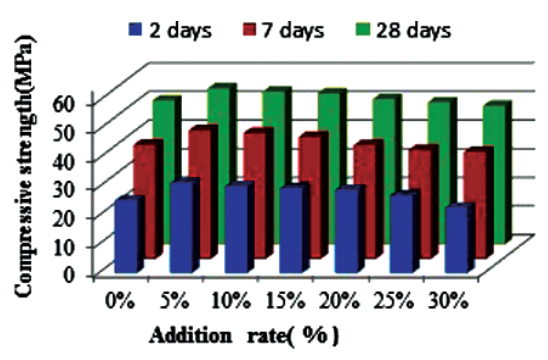

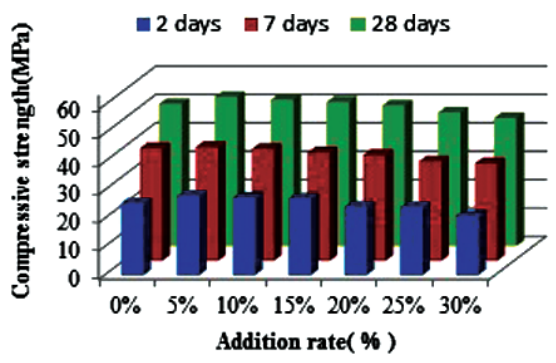

$b$

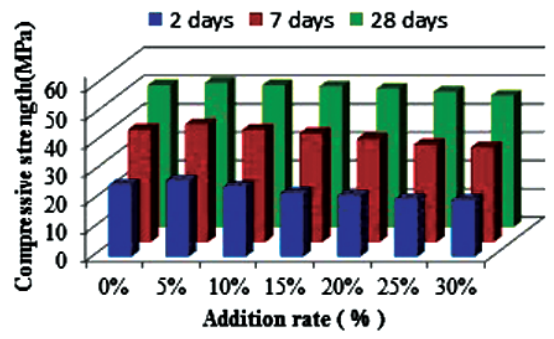

$c$

Fig. 5. Histogram showing the compressive strength as a function of age for cement with different addition:

$a$ - the compressive strength as a function of age for a CWA cement and a cement with phosphate waste rocks additive; $b$ - the compressive strength as a function of age for a CWA cement and a cement with pozzolan additive; $c$ - the compressive strength as a function of age for CWA cement and cement with blast-furnace slag additive

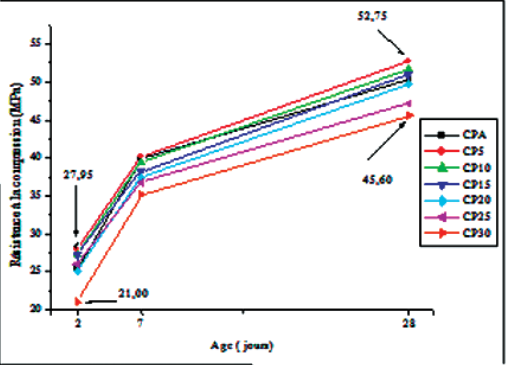

$a$

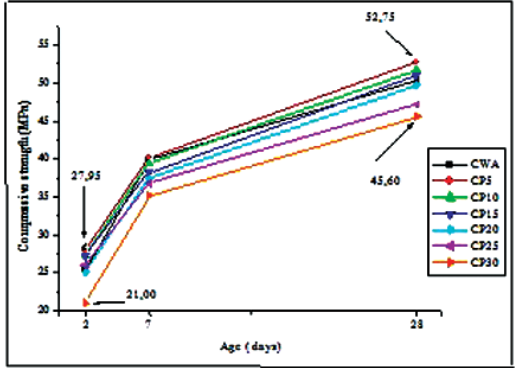

$b$

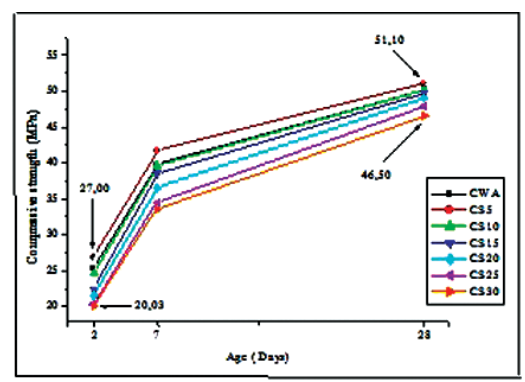

$c$

Fig. 6. Age-dependent compressive strength for CWA cement and cement with different additives:

$a$ - cement with phosphate waste rocks additive; $b$ - cement with pozzolan additive; $c$ - cement with blast-furnace slag additive

all percentages compared with the additive of pozzolan and slag.

Conclusion. From the results of the various tests it is clear that the use of phosphate waste rocks as an additive in the manufacture of cement gives better compressive strengths for all ages and percentages compared to other additives; so this study has shown that it is possible to incorporate a considerable amount of phosphate waste rock from Djebel Onk deposit in the cement, since it also makes it possible to provide the cement with interesting physic-mechanical properties, even with a percentage of additions up to $30 \%$.

According to the results of the tests it can be concluded that this type of cement can be used in: reinforced concrete usually poured on site or prefabricated rapid stripping, quick commissioning concrete steamed or self-parboiled.

Acknowledgments. The authors would like to express their thanks to the staff of the Laboratory of Valorization of Mining Resources and Environment (LAVAMIN), all responsible in the Mining Department of Badji Mokhtar University - Annaba, and to all those who contributed to the acquisition of these results.

\section{References.}

1. Taha Yacin (2017). Valorization of mining waste in the manufacture of cooked bricks: technical and environmental assessments (Thesis presented as partial requirement of the doctorate in environmental sciences). University of Quebec in Abitibi Temiscamingue in cotutelle with the University of Cadi Ayyad, Morocco. https://doi.org/depositum.uqat.ca/id/eprint/697.

2. Senhadji, Y., Escadeillas, G., Mouli, M., Khelafi, H., \& Benosman, S. (2014). Influence of natural pozzolan, silica fume and limestone fine on strength, acid resistance and microstructure of mortar. Powder Technology, 254, 314-323. https://doi.org/10.1016/j.powtec.2014.10.046.

3. People's Democratic Republic of Algeria, Ministry of Spatial Planning and Environment (2002). National Environmen- 
tal Action Plan for the Environment and Sustainable Development (PNAE-DD). Retrieved from http://documents.worldbank.org/curated/en/812481468742850420/Algeria-National-Environmental-Action-Plan-for-sustainable-development-Staff-sector-assessment-note.

4. Abdoulaye Thiam, Alpha Ousmane Toure, Falilou Mbacké Samb, Codou Gueye, \& Mar Diop (2015). Addition of calcium silicate and calcium fluoride mixture to clinker-based mortars. Journal de la Société Ouest-Africaine de Chimie, 40, 41-44.

5. Deboucha, N., Leklou, N., Khelidj, A., Pertue, A., \& Oudjit, M. N. (2017). The effect of blast furnace steel on the porosity of the mortar. In $35^{\text {th }}$ university meetings of civil engineering of the university association of civil engineering. Nantes (FRANCE), May 22-24, 2017. Retrieved from https: org/ rugc17.sciencesconf.org/.

6. Chaib, O., Mouli, M., Hanifi, M., Hamadache, M., Benosman, S., \& Dif, F. (2015). Study of the influence of natural pozzolan on the mechanical strength of mortars based on composite cements. In $33^{r d}$ Meeting of the AUGC, Aquitain Superior Institute of Building and Public Works - ISA-BTP. University of Peu and Pays de l'Adour, Anglet, May 27-29, 2015. Retrieved from https://hal.archives-ouvertes.fr/hal-01167742/.

7. Algerian standard NA 229 "Cement: determination of the normal consistency of the cement paste" (2016). Official journal of the Algerian republic NA 27.

8. Algerian standard NA 442 "Cement: composition, specification and conformity criteria for common cements" (2016). Official journal of the Algerian republic NA 27.

9. Algerian standard NA 234 "Test methods for cement - determination of mechanical strength" (2016). Official journal of the Algerian republic NA 27.

\section{Розробка нового композиційного цементу на основі відходів порід фосфатного родовища Джебель Онк (Тебесса-Алжир)}

\section{С.І. Зегіна, М. Бунуала, М. Четтібі, А. Бенселгуб}

Лабораторія валоризації гірничих ресурсів та навколишнього середовища, Університет Баджі Мохтар, м. Аннаба, Алжир, e-mail: sara_imane@ymail.com

Мета. Основною метою нашої дослідницької роботи $€$ опис характеристик і екологічний менеджмент порожньої породи фосфатного родовища Джебель Онк. Ми пропонуємо валоризацію цього продукту як доповнення до технології виробництва цементу (розробка нового композиційного цементу на основі порожньої породи фосфатного родовища Джебель Онк).

Методика. Проведено порівняльне дослідження фізико-механічних властивостей композиційного цементу на основі фосфатних відходів гірських порід із цементом без добавок (ЦБД) й інших видів цементу на основі добавок із пуццолана й доменного шлаку. Ці добавки становлять, відповідно, при масовому вмісті 5, 10, 15, 20, 25 і 30 \% для кожної добавки.

Результати. Проведені дослідження й випробування дозволили нам зробити висновок: очевидно, що використання фосфатних відходів в якості добавки при виробництві цементу дає кращі межі міцності на стискання в порівнянні з іншими добавками. Таким чином, це дослідження показало, що можна включити до цементу значну кількість фосфатних відходів порід з родовища Джебель Онк.

Наукова новизна. Полягає в можливості скоротити кількість фосфатних відходів порід Джебель Онк з еконо- мічною користю та усунути їх вплив з екологічної точки 3ору.

Практична значимість. Повторне використання відходів в якості альтернативної сировини в будівельних матеpiaлах є багатообіцяючим екологічним рішенням. Цей спосіб валоризації зменшує велику кількість «хвостів» i, отже, їх вплив на навколишнє середовище, а також сприяє збереженню невідновлюваних природних ресурсів, що інтенсивно використовуються в будівництві (глини, вапняк, пісок і т.д.).

Ключові слова: фосфатні відходи порід, доменний шлак, пуциолан, цемент, добавки, родовище Джебель Онк

\section{Разработка нового композиционного цемента на основе отходов пород фосфатного месторождения Джебель Онк (Тебесса-Алжир)}

\section{С. И. Зегина, М. Бунуала, М. Четтиби, А. Бенселгуб}

Лаборатория валоризации горных ресурсов и окружающей среды, Университет Баджи Мохтар, г. Аннаба, Алжир, e-mail: sara_imane@ymail.com

Цель. Основной целью нашей исследовательской работы является описание характеристик и экологический менеджмент пустой породы фосфатного месторождения Джебель Онк. Мы предлагаем валоризацию этого продукта как дополнение к технологии производства цемента (разработка нового композиционного цемента на основе пустой породы фосфатного месторождения Джебель Онк).

Методика. Проведено сравнительное исследование физико-механических параметров композиционного цемента на основе фосфатных отходов горных пород с цементом без добавок (ЦБД) и других видов цемента на основе добавок из пуццолана и доменного шлака. Эти добавки составляют, соответственно, при массовом содержании 5, 10, 15, 20, 25 и 30 \% для каждой добавки.

Результаты. Проведенные исследования и испытания позволили нам сделать вывод: очевидно, что использование фосфатных отходов в качестве добавки при производстве цемента дает лучшие пределы прочности на сжатие по сравнению с другими добавками. Таким образом, это исследование показало, что можно включить в цемент значительное количество фосфатных отходов пород с месторождения Джебель Онк.

Научная новизна. Заключается в возможности сократить количество фосфатных отходов пород Джебель Онк с экономической пользой и устранить их влияние с экологической точки зрения.

Практическая значимость. Повторное использование отходов в качестве альтернативного сырья в строительных материалах является многообещающим экологическим решением. Этот способ валоризации уменьшает большое количество «хвостов» и, следовательно, их воздействие на окружающую среду, а также способствует сохранению невозобновляемых природных ресурсов, интенсивно используемых в строительстве (глины, известняк, песок и т.д.).

Ключевые слова: фосфатные отходы пород, доменный илак, пуииолан, иемент, добавки, месторождение Джебель Онк

Recommended for publication by Dr. Aissi Adel. The manuscript was submitted 18.04.19. 